\title{
Better out than in: why barriers to exit matter for competition law and policy
}

\author{
Matthew Johnson*
}

\begin{abstract}
The issue of barriers to exit has been neglected by competition authorities and by competition policy research. This is somewhat surprising as it is a topic which goes to the heart of why competition policy exists; if barriers to exit prevent or delay inefficient firms from leaving the market, then the normal competitive process of driving up market efficiency is hampered. This in turn reduces the benefits to other, more efficient firms, and to customers in terms of lower prices, better quality, etc. This article explores the reasons why, despite the importance of barriers to exit in the economic framework that underpins competition policy, very few competition authority decisions discuss the issue. It considers the approach to barriers to exit in different types of competition investigation, such as merger assessment, Article 101 and 102 TFEU cases, and State aid. The article also considers the scope for cross-disciplinary research and collaboration, such as in the design of insolvency or bankruptcy laws.
\end{abstract}

Keywords: barriers to exit, competition policy, mergers, antitrust, State aid

\section{Introduction}

The issue of barriers to exit has been neglected by competition authorities and by competition policy research in recent years. This is somewhat surprising as it is a topic which goes to the heart of why competition policy exists. A fundamental concept in competition policy is that the competitive process rewards efficient and innovative firms by allowing them to win customers and so to grow their business and win market share. The same process ensures that inefficient firms lose customers, lose market share, and ultimately exit the market. This process increases the average efficiency of the market. Greater efficiency means doing more with less, which benefits producers and consumers.

If barriers to exit prevent or delay inefficient firms from leaving the market, then the normal competitive process of driving up efficiency by driving out inefficient firms doesn't work as it should. This in turn reduces the benefits to other more efficient firms and to customers, in terms of lower prices, better quality, etc.

This article explores the reasons why, despite the fundamental role of barriers to exit in competition policy, very few competition authority decisions discuss the issue. In section 3 we consider the approach to barriers to exit in different types of competition investigation, such as merger assessment, Article 101 and 102 TFEU cases, and State aid.

\section{The economics: why barriers to exit can harm competition}

\subsection{What is a barrier to exit?}

At its most basic, a barrier to exit is anything that limits the free exit of firms from a market. It is the counterpart to a barrier to entry, which limits free entry of new firms into a market.

From a competition policy perspective, however, a slightly more subtle definition is required. This is because in some cases barriers to exit may be benign or even procompetitive, while in others they can be anti-competitive.

\subsection{Defining an anticompetitive barrier to exit}

To understand the types of exit barriers that are likely to be anti-competitive it is necessary to go back to the basic economic models of industrial organization and the famously unrealistic, but surprisingly useful, economic model of perfect competition. Under conditions of perfect 
competition consumer welfare and allocative efficiency are maximized because competition drives prices down so that they reflect the underlying costs of production. If prices rise above cost, the absence of barriers to entry allows new firms to enter the market and prices are driven back down to marginal costs. Equally, if prices fall below cost, a lack of barriers to exit allows firms to leave the market until prices rise back to a level that covers the costs of production.

There is no generally agreed definition of an anticompetitive barrier to exit. ${ }^{1}$ However, a reasonable candidate definition could be a barrier that reduces market exit by inefficient firms. This definition puts the focus on the underlying competition policy objective of increasing efficiency through a process of rivalry between firms driving out the inefficient and promoting the efficient.

A related issue within this definition is what do we mean by 'market exit'? A firm may exit but its assets may be purchased by others and so remain in the market. There are a number of possibilities. For example, a firm with inefficient assets may exit the market along with all of its assets, or a firm with efficient assets but a poor quality management or commercial strategy may exit the market along with its assets. This has implications for competition and market efficiency and is explored further in the discussion of the 'failing firm defence' in section 3 below.

\subsection{Not all barriers to exit can be charac- terized as barriers to entry}

In some cases barriers to exit can already be foreseen by firms considering whether to enter a market. This may deter them from entering the market, even if, in the absence of the exit barrier, there was a profitable opportunity from market entry. In this type of situation, barriers to exit can be explained simply as a type of barrier to entry.

Barriers to entry are a well understood part of the competition law framework and are often discussed in the context of competition cases. For example, markets with low barriers to entry will often 'self-correct' without the need for intervention. This is because, without significant barriers to entry, any attempt by a firm or group of firms inside the market to raise prices and increase profits will simply attract new entry, which will then drive profits back down to a competitive level.

However, not all barriers to exit can simply be characterized as a type of barrier to entry. When considering whether to enter markets, firms often do not have perfect foresight in terms of how the market may change in the future.

\subsection{Examples of barriers to exit}

A good example of a barrier to exit that is not also a barrier to entry is a change to government regulation that occurs only after firms have entered the market. Take the market for the distribution of petrol through petrol filling stations. These are essentially local markets with firms owning either one, or a network of, filling stations in a particular area. If a firm owns a network of stations it will seek to maximize its profits by ensuring that its stations are located in places where they will be used by as many customers as possible. The optimal network size and shape will change over time as populations change in specific areas, and new sources of demand such as housing estates are built.

Over time, environmental regulations in many countries have become stricter, meaning that if a firm wants to close down a filling station in one location and open a new station in another location that is likely to be more profitable, there can be very significant environmental clean-up costs at the site that is being closed down. In many cases, this is not an exit barrier that could have been foreseen by the firm when deciding to open the site many years ago but is clearly a barrier to exit, which, in some cases may prevent firms from maintaining the most efficient network of locations.

Other examples of barriers to exit can be found in industries that have experienced long periods of growth followed by long periods of decline. One such industry that has been studied in detail by academics is the US steel industry. The industry experienced growth and profitability but this began to decline after 1973. The US industry faced increasing competition from international competitors such as those in China, and by the early 2000s most firms had either been liquidated or had migrated to another industry. ${ }^{2}$

Research by Professor Mary Deily found that a range of barriers delayed the exit of steel firms despite them making losses for a number of years. ${ }^{3}$ The research finds that the key drivers behind the reluctance to restructure and exit include:

- Inability to distinguish cyclical effects from structural changes: this made firms more reluctant to restructure

to exit, available at: https://www.slideshare.net/OECD-DAF/barriers-toexit-deily-december-2019-oecd-discussion.

3 M. Deily (fn 2).

1 OECD Barriers to Exit - Background Note (23 October 2019), Section 2.2.1, available at: https://one.oecd.org/document/DAF/COMP(2019)15/ en/pdf.

2 M. Deily, The effects of exit barriers: evidence from the US integrated steel industry (December 2019), presentation to OECD round table on barriers 
or exit as they believed there was a chance that the industry down-turn might be temporary.

- Low salvage values for the assets of a steel mill, which led to some plants being operated below even variable costs, so as to avoid the costs of bankruptcy (such as severance pay, pension liabilities and environmental remediation). ${ }^{4}$

- Unwillingness of management to downsize firms. There is evidence that even when management was aware of the decline it was often slow to take difficult decisions. Expansion plans were postponed and eventually cancelled, but plant closures were more likely to happen only when a new CEO was brought in to the firm. One possibility is that such an action is harmful to the reputation of an incumbent CEO but much less so to a new CEO. ${ }^{5}$

\subsection{Avoiding the binary fallacy}

Much of the discussion in competition cases around barriers to entry focuses on the act of entry itself; firms either enter or they don't. In the same way, the much more limited discussion on barriers to exit focuses on whether firms leave the market or not. However, this binary approach to entry and exit somewhat misses the point.

When thinking about how low barriers to entry allow markets to 'self-correct' what really matters is not the act of entry but the ability of new entrants to grow and compete effectively with incumbents. Equally, when thinking about barriers to exit, the final act of a firm leaving a market may not have a huge impact on overall efficiency. By contrast, the ability of inefficient firms to restructure, cut back their operations, and potentially divest assets that can be used more efficiently by other players, will reduce the market share of the inefficient firm and so allow overall market efficiency to increase.

\section{Why are barriers to exit rarely assessed in competition cases?}

Part of the reason that barriers to exit are rarely assessed seems to be that they are often seen by competition authorities purely as a type of barrier to entry, in that before firms enter a market they will be able to foresee any costs of exit and this will be factored in to their entry decision. However, as discussed in Section 2.3, that approach addresses only a subset of exit barriers.

4 M. Deily, 'Exit barriers in the steel industry' (1988) 24 Federal Reserve Bank of Cleveland, Economic Review 10, available at: https://www.clevelandfed. org/en/newsroom-and-events/publications/discontinued-publications/ economic-review/1988-economic-review/er-1988q1-exit-barriers-in-thesteel-industry.aspx.

\subsection{Anti-competitive agreements}

The framework for assessing horizontal agreements (and also the horizontal effects on competition caused by vertical agreements) tends to focus on competition between firms that are actual or potential rivals. Barriers to exit are rarely considered as a potential theory of harm.

In most cases this is because the issue of barriers to entry is not directly pertinent to the assessment. The mode of assessment by competition authorities in such cases involves a comparison between the factual situation with the agreement in place and a counterfactual without the agreement. Most barriers to exit would be present in both the factual and the counterfactual situation so would essentially 'net out' over the comparative assessment. In some cases, the agreement itself may create barriers to exit, for example a 'crisis cartel' agreement that is designed to support firms that may otherwise exit the market during a downturn. However, such cases are rare.

\subsection{Abuse of dominance}

The framework for assessing abuse of dominance focuses on market definition, market power and abuse of market power. Although in recent years there has been an increase in abuse of dominance cases that are concerned with excessive pricing, the vast majority of cases focus on the exclusion of rivals from the market by the dominant firm.

The so-called 'as efficient competitor' test, which can be used to assess exclusionary abuse of dominance, ensures that the application of Article 102 TFEU is in line with the economic models discussed in Section 2 above. At a high level the test is designed to differentiate between situations where a dominant firm has excluded a less efficient rival (which may be a pro-competitive outcome, depending on the remaining market structure post-exit), or excluding an equally or more efficient competitor, which is likely to be anti-competitive. This approach demonstrates that Article 102 does not in itself act as a barrier to exit for inefficient firms.

\subsection{Merger control}

Standard merger control theories of harm (unilateral effects, coordinated effects, vertical foreclosure and conglomerate effects) could in principle be impacted by the presence of exit barriers. However, many merger control regimes focus on the incremental impact of a merger on

5 M. Deily, 'Exit strategies and plant closing decisions: the case of steel' (1991) 22 Rand Journal of Economics 250. 
competition, compared to the counterfactual in which the merger did not occur. ${ }^{6}$ It is unlikely that a merger would in itself increase or decrease barriers to exit so these barriers are often taken as a given in both factual and counterfactual scenarios, so, as discussed above in relation to anti-competitive agreements, the effect of exit barriers tends to 'net out' when authorities are assessing the impact of a merger on competition.

\section{a. The 'failing firm defence' in merger control}

The 'failing firm defence' or 'exiting firm scenario' is used in merger control where the target firm is in severe financial difficulties and likely to exit the market rapidly in the absence of the merger. In such circumstances, the merger may be unlikely to harm competition because, either way, the target firm will no longer be a competitive force in the market.

This is one area within merger control where the issue of barriers to exit becomes more relevant, if only tangentially. A strict application of the 'failing firm defence' could in itself be seen as a barrier to exit if it deters inefficient firms from exiting the market and selling their assets to their more successful or efficient competitors.

However, the impact is hard to judge as it depends on a number of factors. For example, if in the counterfactual:

- The target firm and its inefficient assets would exit the market, it may be better to block the merger. This is because unless the acquirer can take the inefficient assets and turn them into efficient ones, the market may be better off if these assets exit along with the failing firm.

- The target firm and its efficient assets would exit the market, it may be better to clear the merger as the merger would allow the efficient assets to remain in the market.

- The target firm would exit but its inefficient assets would stay in the market, it may be safe to clear the merger. This rather counterintuitive result arises because with or without the merger the inefficient assets stay in the market and so there is no impact from the merger itself.

\subsection{State aid}

State aid is the area of competition enforcement where the issue of barriers to exit is most clearly in focus.
This is clear from State aid guidance and from the decisional practice of the Commission.

\section{a. European Commission guidance and decisional practice}

The Commission's guidance on rescue and restructuring aid makes clear that such aid should be given on a 'one time, last time' basis. ${ }^{7}$ This is to prevent fundamentally inefficient firms from being continually propped up by injections of State aid over time, but allows for aid in a situation where, following a restructuring of its operations, a firm can go on to be an efficient operator without the need for further aid. If, following the receipt of aid, the firm fails to turn itself around it will then exit the market as further aid will not be permitted.

The importance of limiting distortions to competition caused by aid to firms that would have otherwise exited the market is also reflected in the Commission's State aid decisional practice for rescue and restructuring cases. A clear example of this is the remedies imposed on banks who received aid during the 2008/09 financial crisis. The Commission approved the aid to many banks as being compatible with the State aid rules, but this was conditional on the banks agreeing to a restructuring plan, which amongst other things, was designed to limit distortions to competition created by the aid.

In the case of Allied Irish Banks (AIB), one of the largest domestic banks in Ireland, the restructuring plan agreed with the Commission included: ${ }^{8}$

- Structural measures: these focused on the divestment of 'non-core' assets, which, in the event that the bank had not received State aid, it may have had to sell in order to re-build its balance sheet. The sell-off included more than 10 businesses within the group, many of them outside Ireland. It also included the closure of 112 local branches, leaving the bank with $274 .^{9}$

- Behavioural measures: these included restrictions on lending, which would allow other, non-aided, players to grow market share at AIB's expense. ${ }^{10}$

In the case of Lloyds Banking Group in the UK, which also received aid during the financial crisis, the branch divestiture part of the restructuring package was even more extensive. Lloyds sold 631 of its branches and associated
6 Such as the substantial lessening of competition (SLC) test used in the US and the UK.

7 European Commission, Guidelines on State aid for rescuing and restructuring non-financial undertakings in difficulty (2014) O.J. C 249/1, section 3.6.1. There are a number of exceptions to the 'one time, last time' principle; one such exception involves cases of exceptional and unforeseeable circumstances for which the beneficiary is not responsible: see section 6.5(d).
8 European Commission, Decision (EU) 2015/218 on the State aid [...] implemented by Ireland for the restructuring of Allied Irish Banks plc and EBS Building Society (7 May 2014) (2015) O.J. L 44/40.

9 Allied Irish Banks plc and EBS Building Society (fn 8), para 50.

10 Allied Irish Banks plc and EBS Building Society (fn 8), paras 65, 86 and 107. 
customers to Sabadell Group, along with the TSB brand, allowing Sabadell, which was not present in the UK at the time, to enter the market with around a 5\% current account market share. ${ }^{11}$ This represented up to $25 \%$ of Lloyds current account business ${ }^{12}$ and just under $20 \%$ of its mortgage business.

Although criticized by some practitioners, ${ }^{13}$ a clear aim of these measures was to reduce the market share of aided banks in order to reduce the distortion caused by banks with poor quality assets and/or ineffective risk management being allowed to retain a major role in their respective national markets.

\section{Conclusions and areas for further research}

Reducing barriers to exit for inefficient firms is an important element of competition policy, but one that is often overlooked. This goes beyond the application of competition law in enforcement cases; some competition authorities have a wider role in terms of competition advocacy across government and exit barriers is an area where further research may open up new avenues for improving competition.

A case in point is the area of insolvency or bankruptcy laws. Depending on the design of such laws, they may create barriers to exit, keeping inefficient firms in existence for too long, or they can act as a facilitator, allowing the smooth exit of inefficient firms. However, as Professor Jocelyn Martel pointed out in his remarks to the OECD round-table on barriers to exit, bankruptcy and antitrust laws may have conflicting objectives, and in the case of financially distressed firms, competition issues sometimes take second place to bankruptcy issues. ${ }^{14}$

Other areas that would benefit from further research include the extent to which we can consider separately inefficient firms and their efficient or inefficient assets, and also understanding the set of circumstances in which the rivalry benefits of having an inefficient firm remain in the market are likely to outweigh the efficiency benefits of them shrinking and ultimately exiting.
11 Lloyds Banking Group, Rights Issue and Capital Enhancement Proposals (3 November 2009), slide 11, available at: https://www.lloydsbankinggroup. com/globalassets/documents/investors/2009/2009nov3_lbg_analyst_presen tation.pdf.

12 European Commission, Case State aid No. N 428/2009 - United Kingdom Restructuring of Lloyds Banking Group (18 November 2009), para 16.
13 C. Ahlborn and D. Piccinin, 'Bank Restructuring aid in the financial crisis', Oxera Agenda (September 2009), available at: https://www.oxera.com/wpcontent/uploads/2018/03/Bank-restructuring-aid_1.pdf.

14 J. Martel, Bankruptcy law and barriers to exit, presentation to OECD roundtable, slides 17-18, available at: https://www.slideshare.net/OECDDAF/barriers-to-exit-martel-december-2019-oecd-discussion. 